\title{
Statyba
}

\section{STOCHASTIC STABILITY PROBLEMS IN STRUCTURAL MECHANICS}

\section{Prof Dr Techn Ch. Bucher}

To cite this article: Prof Dr Techn Ch. Bucher (1997) STOCHASTIC STABILITY PROBLEMS IN STRUCTURAL MECHANICS, Statyba, 3:10, 18-23, DOI: 10.1080/13921525.1997.10531679

To link to this article: https://doi.org/10.1080/13921525.1997.10531679

册 Published online: 26 Jul 2012.

Submit your article to this journal \lceil

山 Article views: 48

7 Citing articles: 1 View citing articles 


\section{STOCHASTIC STABILITY PROBLEMS IN STRUCTURAL MECHANICS}

\section{Ch. Bucher}

\section{Introduction}

Several recent developments in the analysis of systems with random properties focus on the appropriate description of non-linear effects. Apart from physical non-linearity as introduced by specific material properties (such as yield stress), there is the geometrical non-linearity which is closely related to the question of structural stability. In terms of the practical computation, the issue of stochastic stability breaks down to the determination of the top Lyapunov exponent of the system. For details it is referred to [1]. Confining the analysis to local stability, the system generating the trajectories $x(t)$ can be linearized at the solution $x_{0}(t)$ whose stability is to be investigated.

The stability of the system will depend on both system properties and loading parameters. Therefore it is to be expected that stability can be influenced by system uncertainty. An appropriate tool for taking into account geometrical non-linearity of complex structures together with the randomness of the describing parameters is the Stochastic Finite Element Method (SFEM). Among various SFE techniques developed so far ([2] - [6]), the methods based on representation of the underlying random fields in the integration points seem to be most suitable [7]. Based on this random field model, a corresponding finite element model can be established. With the aid of eg the Monte Carlo simulation technique, the variability of the response is investigated [8]. The following discussion attempts to cover stability issues under both static and dynamic loading conditions, specifically under wide band random excitation.

\section{General Concept}

\subsection{Linearized Equations of Motion}

Most structural systems of engineering significance cannot be described in such relatively simple terms. Discretization must be performed which finally leads to a finite element model. Applying equilibrium conditions in the nodes, a dynamic analysis of geometrically non-linear structures generally requires the solution of the following matrix-vector equation

$$
[M] \ddot{x}+[C] \dot{x}+r(x)=f(t) .
$$

In (1) $[M]$ is the mass matrix, $[C]$ is the damping matrix, $x$ denotes the vector of nodal displacements, $r(x)$ is the vector of restoring forces depending nonlinearly on the nodal displacements, and $f(t)$ is the applied load. It cannot be decided a priori whether this load acts additively or multiplicatively. Some investigation is required for that purpose.

Suppose, for simplicity, loading conditions which can be described by a scalar, possibly time-dependent multiplier $\mu(t)$ (load factor) and a constant load configuration vector $\boldsymbol{p}$

$$
f(t)=\mu(t) p .
$$

Then the parametric excitation effect can be expressed explicitly by a series expansion in respect of $\mu(t)$ (Taylor series):

$$
\begin{aligned}
& r(x)=r\left(x_{0}\right)+\left.\frac{\partial r}{\partial \mu}\right|_{\mu=\mu_{0}}\left(\mu(t)-\mu_{0}\right) \\
& +\left.\frac{1}{2} \frac{\partial^{2} r}{\partial \mu^{2}}\right|_{\mu=\mu_{0}}\left(\mu(t)-\mu_{0}\right)^{2}+\ldots
\end{aligned}
$$

Here $\mu_{0}$ is a (fairly arbitrary) reference value for the load factor and $x_{0}$ is implicitly defined to be the solution of

$$
r\left(x_{0}\right)=f_{0}=\mu_{0} p
$$


As mentioned above, for the purpose of stability analysis, the system is linearized at the solution whose stability is to be investigated. In the following it is assumed, that the linearization point is defined by the static solution $x_{0}$ as implicitly given by (4). Strictly speaking, this assumption is useful for static stability only. In the presence of both external and parametric random excitations the reference solution $x_{0}$ whose stability is to be investigated is randomly varying in time. If it can be assumed that the relative effect of the random fluctuations of the external and parametric excitation on the system non-linearity is small as compared to the effect of the statically acting part of the excitation, then it is reasonable to replace the non-linear system by a system linearized at a constant solution. This is the case, eg for wind loads acting on large scale structures where the mean wind load is significantly higher than the random fluctuations caused by atmospheric turbulence. In addition, (3) is frequently linearized in respect of $\mu(t)$ following a similar argument [9].

The so-called tangential equation of motion can then be written as

$$
\begin{aligned}
{[M] \ddot{y}+[C] \dot{y} } & +[K] y= \\
& =f(t)-f_{0}=\left(\mu(t)-\mu_{0}\right) p
\end{aligned}
$$

in which $y$ denotes the deviation from the reference solution, i e $y=x-x_{0}$. The elements of the tangential stiffness matrix become

$$
K_{i j}=\left.\frac{\partial r_{i}(x)}{\partial x_{j}}\right|_{x=x_{0}} .
$$

In the above equation (6), the partial derivatives are evaluated at the reference solution $x=x_{0}$.

For the description of parametric excitation effects, it is convenient to introduce the concept of a so-called geometric stiffness matrix.

This arises from an additional linearization step (3):

$$
[\boldsymbol{K}] \boldsymbol{y}=\left[\boldsymbol{K}_{0}\right] \boldsymbol{y}+\left[\frac{\partial \boldsymbol{K}}{\partial \mu}\right]_{\mu=\mu_{0}}\left(\mu(t)-\mu_{0}\right) \boldsymbol{y}
$$

with the "linear" stiffness matrix $\left[K_{0}\right]$ and the geometric stiffness matrix $\left[K_{\mathrm{G}}\right]$ in the form of

$$
\left[\boldsymbol{K}_{0}\right]=\left[\boldsymbol{K} \|_{\mu=\mu_{0}} ;\left[\boldsymbol{K}_{G}\right]=\left[\frac{\partial \boldsymbol{K}}{\partial \mu}\right]_{\mu=\mu_{0}} .\right.
$$

This finally leads to an equation of motion which is linear in the state variables and explicitly separates the effects of additive and multiplicative excitations.

$$
\begin{array}{r}
{[M] \ddot{y}+[C] \dot{y}+\left[K_{0}\right] y+\left[K_{G}\right] y\left(\mu(t)-\mu_{0}\right)} \\
=\left(\mu(t)-\mu_{0}\right) p .
\end{array}
$$

Obviously, a static instability is possible whenever the tangential stiffness matrix becomes singular. This implicitly defines a critical load factor $\mu_{c}$ in terms of (10).

$$
\operatorname{det}[\boldsymbol{K}]=\operatorname{det}\left[\boldsymbol{K}\left(\boldsymbol{\mu}_{c} \boldsymbol{p}\right)\right]=0 .
$$

It is to be noted that together with the linearized equation of motion (9) this corresponds to the widely used approximation of the critical load factor $\mu_{c}$ as solution of the eigenvalue problem

$$
\operatorname{det}\left(\left[\boldsymbol{K}_{0}\right]-\mu_{c}\left[\boldsymbol{K}_{G}\right]\right)=0 .
$$

\subsection{Dynamic Stochastic Stability}

Based on the linearized equation of motion (11), any available method for the stochastic stability analysis of linear systems can be applied. In the present paper, a simplified analysis for the sample stability (almost sure stability) criterion is used. The method is based on stochastic averaging. The details of the approach to be followed have been presented extensively by [10]. This approach requires the projection of the motion onto one mode of vibration which is most likely to become unstable under the influence of random parametric excitation. Here it is assumed that $\mu(t)$ is a wide band stationary random process. Possible stabilisation from the remaining, more stable modes can be accounted for. The resulting sample stability boundaries obtained from this method are asymptotically exact as the system reaches the deterministic stability limit. Therefore, this is an approach well suited for the assessment of the parametric excitation effect near such a deterministic stability limit. In this case, the motion is predominantly governed by one critical mode of vibration $\phi_{C}$ as described by 


$$
\left([K]-\omega_{c}^{2}[M]\right) \phi_{c}=0 .
$$

This mode shape is assumed to be mass-normalised, so that

$$
\phi_{c}^{\mathrm{T}}[\boldsymbol{K}] \phi_{c}=\omega_{c}^{2} ; \quad \phi_{c}^{\mathrm{T}}[\boldsymbol{M}] \phi_{c}=1 .
$$

Of particular importance is the parametric excitation effect which is expressed in terms of

$$
d=\phi_{c}^{\mathrm{T}}\left[K_{G}\right] \phi_{c} .
$$

With the assumption of a modal damping ratio $\zeta$ associated with the critical mode $\phi_{\mathrm{c}}$ and - for the sake of simplicity -neglecting the effect of modal coupling through the parametric excitation, the top Lyapunov exponent $\lambda$ of the system governing sample stability can be expressed as in [11]

$$
\lambda=-2 \xi \omega_{c}+\frac{d^{2}}{4} S_{\xi \xi}\left(2 \omega_{c}\right)
$$

In (15) $S_{\xi \xi}\left(2 \omega_{c}\right)$ is the power spectral density of the zero mean parametric excitation $\xi(t)=\mu(t)-E[\mu]$ evaluated at twice the frequency of the critical mode. A value of $\lambda<0$ indicates a system which is asymptotically stable with probability 1 . This condition is less stringent than eg moment stability, but it is expected to bear more physical relevance.

\section{Applications}

\subsection{Buckling of Physically Imperfect Beam Structure}

A steel structure consisting of beams with tubular cross-sections under static and dynamic load is considered (see Fig 1).

The load $F(t)$ acts simultaneously as external and as parametric excitation. The FE-model has 78 degrees of freedom. First of all, a deterministic incremental static analysis to determine the critical load factor is performed. All the loads as indicated in Fig 1 are varied proportionally.

This is achieved by incrementing the load factor $\mu_{0}$ in small steps, solving for the corresponding displacements, re-calculating the tangent stiffness matrix $[K]$ and checking its positive definiteness. As soon as at least one eigenvalue of $[K]$ reaches zero, the system has reached a critical load $\left(\mu_{0}=\mu_{\mathrm{c}}\right)$. The smallest eigenvalue of the tangent stiffness matrix is plotted versus the load factor $\mu_{0}$ in Fig 2. The eigenvector corresponding to the zero eigenvalue at $\mu$ ${ }_{0}=\mu_{\mathrm{c}}$ is called buckling shape. For the particular structure under consideration, the buckling shape in reference to the undeformed configuration is shown in Fig 3.

It should be noted that for this structure there is no way of isolating the parametric (destabilizing) contribution of the load $F(t)$ a priori. Indeed, only a procedure as outlined above can provide the desired answer.

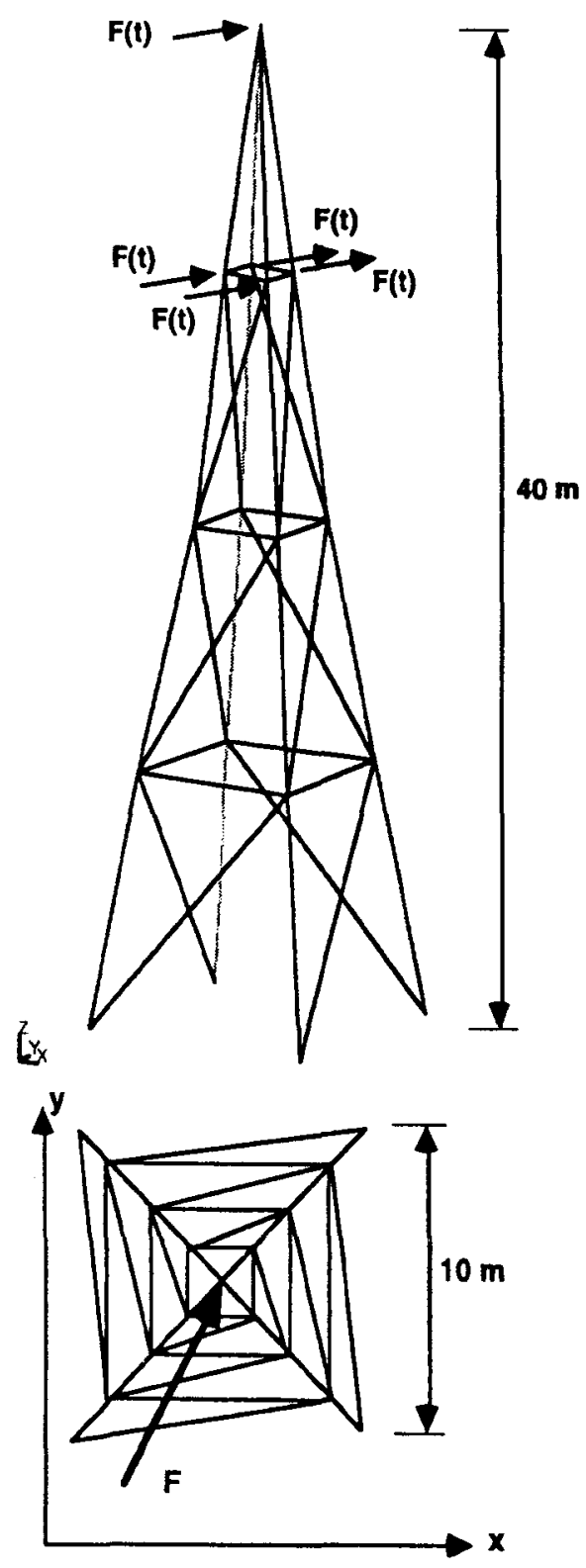

Fig 1. Steel structure with load 


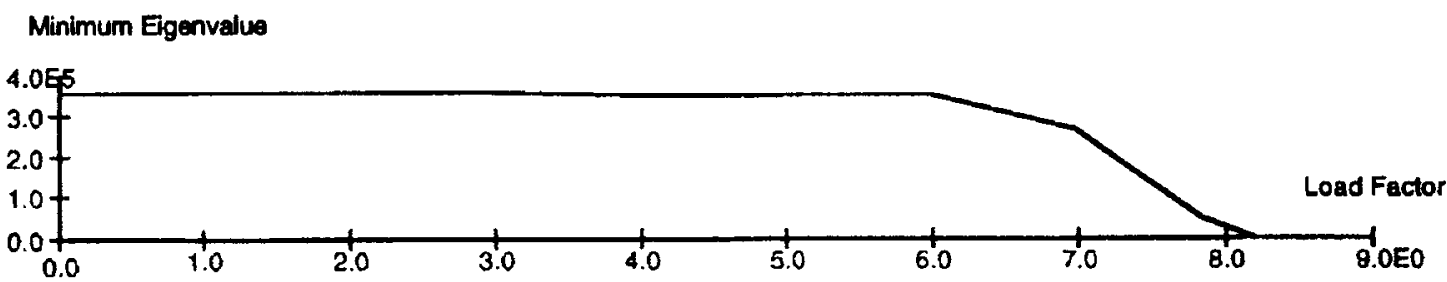

Fig 2. Minimum eigenvalue vs. load factor

In the second step, the elastic modulus $E(s)$ of each vertical bar is assumed to be a homogeneous random field with log-normal probability distribution and an exponential type autocorrelation function

$$
C_{E E}(s, r)=\sigma_{E}^{2} \exp \left(-\frac{\|s-r\|}{L_{c o r r}}\right)
$$

In (16) the symbols $s, r$ denote spatial coordinates within the structure, $\sigma_{E}{ }^{2}$ is the variance of the elastic modulus, and $L_{c o r}$ is the correlation length of the random field. The horizontal and diagonal bars are assumed to have deterministic elastic properties. For the calculations, it is assumed that the mean value and the standard deviation of the elastic modulus are $\bar{E}=2.1 \cdot 10^{11} \mathrm{~N} / \mathrm{m}^{2}, \sigma_{E}=0.1 \bar{E}$, and that its correlation length is $L_{\text {corr }}=20 \mathrm{~m}$.

The effect of structural randomness on the load carrying capacity (in terms of the critical load factor $\left.\mu_{c}\right)$ is investigated. This is done by an iterativeincremental method based on a modified NewtonRaphson-iteration. The loads are incremented by changing the load factors $\mu_{0}$ and at each step calculating the eigenvalues of the tangent stiffness matrix $[K]$. Here the geometric stiffness matrix is not explicitly required.

A Monte-Carlo simulation based on the above assumptions is performed. For each sample, a realisation of the random field $E(r)$ is generated in all integration points and the system matrices are built. The resulting realisations of the critical load factor $\mu_{c}$ are shown as a histogram from 1000 samples in Fig 4. This histogram represents a coefficient of variation of 0.07 .

\subsection{Motion Stability of Suspension Bridge}

A simple bridge model with two mechanical degrees of freedom is considered as investigated in [12]. The model parameters are considered to be deterministic. The effect of random turbulence in the oncoming wind is shown in Fig 5.

This figure indicates an increase of the critical wind speed with increasing level of turbulence as compared to an almost laminar flow in the oncoming wind. The overall effect of turbulence at high levels, however, is destabilizing for the bridge vibration. These statements hold for both second moment stability and almost sure stability criteria.

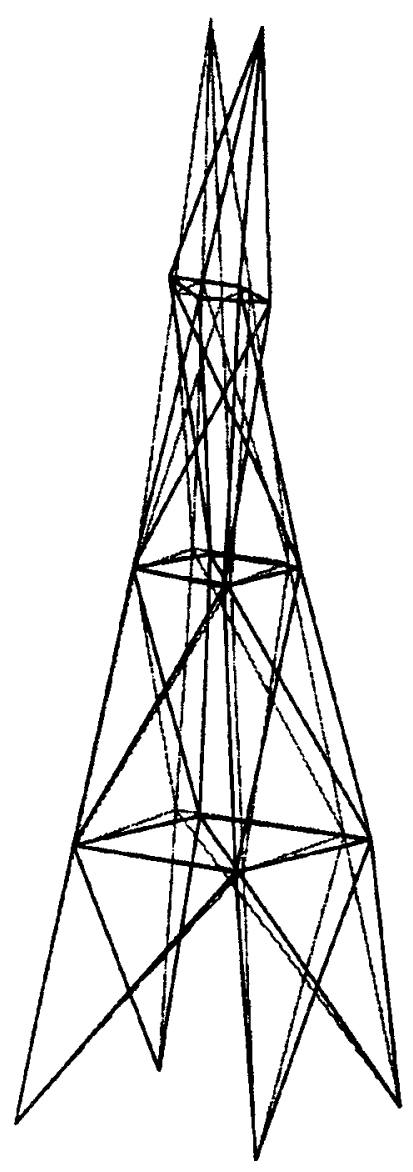

Fig 3. Deterministic buckling shape 


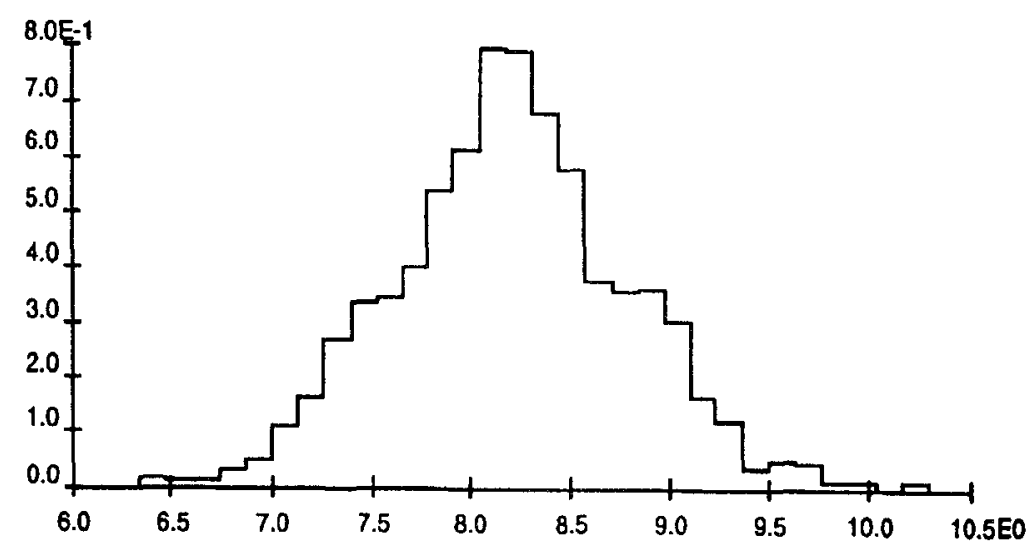

Fig 4. Histogram of critical load factor with random elastic modulus

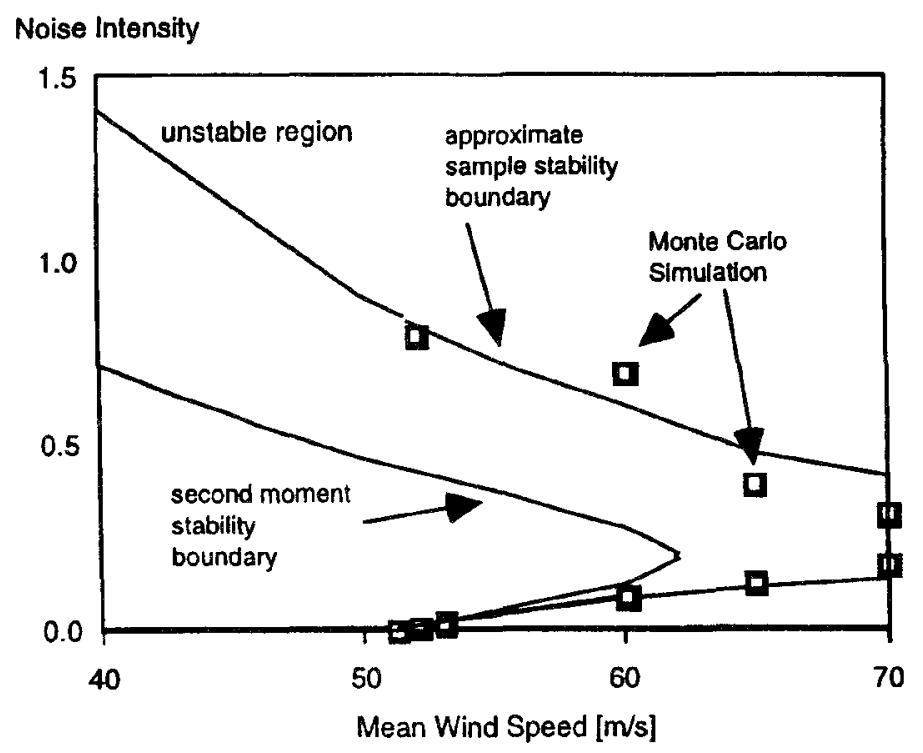

Fig 5. Critical mean wind speed vs. level of turbulence

\section{Concluding Remarks}

A concept for the stability analysis of geometrically non-linear structures with random properties has been presented. Numerical examples showed how the issues of parametric excitation and system randomness can be covered simultaneously within a Stochastic Finite Element method.

The numerical results indicate that there is a quite considerable effect of material randomness on the load-carrying capacity of geometrically non-linear structures. This statement holds for both static and random dynamic loading.

\section{References}

1. F. Kozin. Some results on stability of stochastic dynamical systems // Random Vibration - status and recent development. I. Elishakoff and R.H. Lyon (eds.), Elsevier, Amsterdam, 1986, pp 163 - 191.

2. W. K. Liu, A. Belytschko, A. Mani. Probabilistic Finite Elements for Non-linear Structural Dynamics // Computer Methods in Applied Mechanics and Engineering, 56, 1986, p. 61-81.

3. G. Deodatis, M. Shinozuka. Stochastic FEM Analysis of Non-linear Dynamic Problems in Spanos // robabilistic Methods in Civil Engineering, Proceedings of the 5th ASCE Specialty Conference, Blacksburg, VA, May 25-27,1988, p. 152-155. 
4. T. Hisada, H. Noguchi. Development of a Non-linear Stochastic FEM and its Application // Struct. Safety \& Reliability. M. Shinozuka, G.I. Schueller (eds.). Proceedings of the 5th ICOSSAR, ASCE, San Francisco, CA, 1989, p. 1097-1104.

5. T. Takada. Fundamental study on application of Stochastic Field theory to engineering. ORI Report 9102, Ohsaki Research Institute, Shimizu Corporation. 1991. $221 \mathrm{p}$.

6. C.E. Brenner. Ein Beitrag zur Zuverlässigkeitsanalyse großer Strukturen unter System- und Lastunsicherheiten mit Hilfe der Methode der Stochastischen Finiten Elemente. Dissertation, Faculty of Civil Engineering and Architecture, University of Innsbruck, Innsbruck, Austria, 1995. 216 p.

7. C.E. Brenner. On Methods for Non-linear Problems Including System Uncertainties // Structural Safety and Reliability Schueller, G.I.; Shinozuka, M.; Yao, J.T.P. (eds.). Proc. ICOSSAR 93 Balkeema, Rotterdam, 1994, p. 311 - 317.

8. C.G. Bucher, M Shinozuka. Structural Response Variability II // Journal of Engineering Mechanics, 114 (12), 1988, p. 2035 - 2054.

9. Y.K. Lin, S.T. Ariaratnam. Stability of Bridge Motion in Turbulent Wind // J. Struct. Mech., 8(1), 1980, p. 1 15.5.

10. N. SriNamachchivaya, Y.K Lin. Application of stochastic averaging for systems with high damping // Probabilistic Engineering Mechanics, 3(3), 1988, p. 159 - 167.

11. N. SrilJaraachchivaya, Stochastic Bifurcation // Applied Mathematics and Computation, 38, 1990, p. 101 - 159.

12. C. Bucher, Y.K Lin. Stochastic Stability of Bridges Considering Coupled Modes // J. Eng. Mech., ASCE, Vol. 114, No 12, 1988, p. 2055 - 2071.

Iteikta 19970220

\section{STOCHASTINIAI KONSTRUKCIJU MECHANIKOS STABILUMO UŽDAVINIAI}

\section{Ch. Bucher}

\section{Santrauka}

Straipsnyje nagrinejjamas konstrukciju su atsitiktinèmis savybemis stabilumas. Tokios konstrukcijos yra veikiamos statiniy bei atsitiktiniy dinaminiy apkrovy. Tiriama priklausomybė tarp konstrukcijos savybiu ir parametrinès apkrovos rodikliu. Stochastinių baigtinių elementy idejja taikoma geometriškai netiesinių sistemy analizei.

Stabilumo uždavinys yra nagrinejjamas tiek statinio, tiek dinaminio stabilumo prasme. Išanalizavus apibendrintos diskrečiosios sistemos judejimo lygtis (1-9), stabilumo uždavinys formuluojamas kaip tikriniu reikšmiu uždavinys (10-11) nežinomo apkrovos daugiklio atžvilgiu. Tam tikrais atvejais dinaminio stabilumo uždavinys virsta kritinès virpesių formos stabilumo uždaviniu (12-13).

Stochastinis stabilumo uždavinys yra realizuotas programu paketo pavidalu, o straipsnyje pateikiami išspręsti skaitiniai pavyzdžiai. Pirmajame pavyzdyje nagrinejamas erdvinès strypinès sistemos statinis stabilumas. Cia strypy tamprumo modulis yra atsitiktinis dydis. Jo atsitiktinès savybès modeliuojamos Monte Karlo metodu. Išnagrinèta kritines apkrovos rodiklio priklausomybe nuo atsitiktiniu veiksnių. Skaixiavimo rezultatai iliustruojami 1-4 paveikslais. Antrame pavyzdyje nagrinejamas tilto stabilumas veikiant dinaminems stochastinès prigimties apkrovoms, 5 pav.

Christian BUCHER. Prof Dr techn, Bauhaus-University Weimar, Marienstrasse 15, D-99421 Weimar, Germany.

Professor at Institute of Structural Mechanics, Faculty of Civil Engineering. Diploma in Civil Engineering in 1982, $\mathrm{PhD}$ in 1986, Habilitation in 1989 at University of Innsbruck, Austria. Research interests: stochastic structural dynamics, software development. 